\title{
Anti-Cancer Activity Based on the High Docetaxel Loaded Poly(2-Oxazoline)s Micelles [Corrigendum]
}

$\mathrm{Xu}$ M, Yao $\mathrm{C}$, Zhang $\mathrm{W}$, Gao S, Zou $\mathrm{H}$, Gao J. Int J Nanomedicine. 2021;16:2735-2749.

The authors have advised the Acknowledgment statement on page 2748 is incorrect. The acknowledgment section should read as follows:

\section{Acknowledgments}

The authors acknowledge the formulation for the docetaxel in Poly(2-oxazoline) micelles previously developed and published by the Kabanov lab with reference to Seo Y, Schulz A, Han Y, et al. Poly (2-oxazoline) block copolymer based formulations of taxanes: effect of copolymer and drug structure, concentration, and environmental factors. Polym Adv Technol. 2015;26(7):837-850 (https://doi.org/10.1002/pat.3556). ${ }^{24}$ The current article reports the authors original research evaluating this polymeric micelle formulation of docetaxel in their own animal models. Dr Jing Gao wishes to acknowledge her time spent as a visiting scholar to the Kabanov lab at UNC-Chapel Hill from 2013-2014. This study was supported by Military Medical Innovation Project (16CXZ032), National Science and Technology Major Projects for "Major New Drugs Innovation and Development" (No. 2018ZX09J18107-003, 2018ZX0 9721003-005-009) and NSFC projects (No. 81773278, 81702491).
International Journal of Nanomedicine

\section{Publish your work in this journal}

The International Journal of Nanomedicine is an international, peerreviewed journal focusing on the application of nanotechnology in diagnostics, therapeutics, and drug delivery systems throughout the biomedical field. This journal is indexed on PubMed Central, MedLine, CAS, SciSearch ${ }^{\mathbb{B}}$, Current Contents ${ }^{\mathbb{B}} /$ Clinical Medicine,

\section{Dovepress}

Journal Citation Reports/Science Edition, EMBase, Scopus and the Elsevier Bibliographic databases. The manuscript management system is completely online and includes a very quick and fair peer-review system, which is all easy to use. Visit http://www.dovepress.com/ testimonials.php to read real quotes from published authors. 